\title{
Aikuiskoulutukseen osallistuminen Suomessa
}

\author{
Mitä tiedämme, kun saamme tietää jonkun osallistuvan \\ aikuiskoulutukseen? Emme paljoakaan. Aikuiskoulutuksen \\ tarjonta on monimuotoisuudessaan pirstaleinen ja sen kysyntä \\ on väestöryhmittäin eriytynyt. Omaehtoisesti harjoitetut \\ aikuisopinnot eivät enää 2010-luvulla tyhjentävästi kuvaa \\ aikuiskoulutukseen osallistumista.
}

$\mathbf{y}$

AIKUISKOULUTUKSEEN osallistumisen malleissa osallistumista jäsennetään usein ikään kuin aikuiskoulutus olisi yhtenäinen kokonaisuus. Opiskelu harrastuksen vuoksi ja itsensä sivistämiseksi poikkeaa kuitenkin täysin esimerkiksi työnantajan henkilöstölleen järjestämästä työpaikkakoulutuksesta tai työvoimaviranomaisen työttömälle työnhakijalle osoittamasta työvoimapoliittisesta kurssista. Osallistumista tarkasteltaessa on entistä tärkeämpää ottaa lähtökohdaksi se, mistä koulutusmuodosta on kysymys.

Tarkastelemme tässä artikkelissa aikuiskoulutukseen osallistumista Tilastokeskuksen keräämän Aikuiskoulutustutkimus 2012 -aineiston avulla.
Analysoimme (1) osallistumisen jakautumista eri koulutustyyppeihin ja (2) osallistumisasteita koulutustyypeittäin sosioekonomista asemaa osoittavien taustatekijöiden mukaan. Ennen tätä empiiristä osaa keskustelemme aikuiskoulutukseen osallistumisen muuttumisesta viime vuosikymmenten aikana ja aikuiskoulutukseen osallistumisen teoreettisista malleista.

\section{VIELÄKÖ AIKUISKOULUTUS ON ERITYISTÄ?}

Koulutuksen historiallisista syistä aikuiskoulutuksen osallistumisen tutkimuksessa on korostunut yksilön näkökulma. 1900-luvun alusta aina 1970-luvulle saakka koulutus oli nimenomaan lapsuuteen ja 
nuoruuteen elämänvaiheena kuuluvaa toimintaa, ja aikuisen kouluttautuminen oli poikkeuksellista. Oppivelvollisuuden vuoksi lasten koulutus oli pakollista 16-vuotiaaksi asti. Erotuksena oppivelvollisten lasten ja nuorisoasteen koulutuksesta aikuisten kouluttautuminen oli vapaaehtoista ja perustui yksilön omaan päätökseen.

Iso osa aikuisten koulutuksesta oli osallistumista vapaan sivistystyön opintoihin, joihin liittyi vahva mielikuva itsensä kehittämiseen herätyksen saaneesta aikuisesta. Todellisuudessa aikuiskoulutus oli alun perin sosiaalisesti ja kulttuurisesti ylhäältä alaspäin organisoitua "kansan" moraalista sääntelyä, köyhän väestönosan hallintaa. (Koski 2011.) Koulutukseen osallistuminen nähtiin oppimishaluisen aikuisen yksilön aktiivisuutena. Osallistumisen syitä oli luontevaa etsiä poikkeuksellisesta tiedonhalusta ja oppimishalukkuudesta sekä motivaatiopsykologisista tekijöistä.

Knud Illeris kuvaa aikuiskoulutuksen ja aikuisena oppimisen erityisyyttä seuraavasti:

Toisin kuin lasten oppiminen, joka on perusolemukseltaan avointa ja luottavaista (fundamentally uncensored and confident), aikuisten oppimisen tärkein piirre on valikoivuus. Aikuisena oleminen merkitsee sekä lainsäädännöllisesti että psykologisesti sitä, että yksilön odotetaan ottavan, ja että hän kykenee ottamaan, vastuun omasta toiminnastaan. Tämä on sellaisten korkealle arvostettujen käsitteiden kuten vapauden ja demokratian ytimessä, ja se pätee myös aikuisten oppimiseen: aikuiset oppivat mitä haluavat oppia ja minkä oppiminen on heille mielekästä, oppiessaan aikuiset käyttävät omia voimavarojaan, he ottavat niin paljon vastuuta oppimisestaan kuin haluavat (jos heille suodaan siihen mahdollisuus), ja heillä on taipumus vältellä, hyljeksiä tai vähätellä sellaisia oppimistilaisuuksia, joita he eivät näe mielekkäinä tai johon heillä ei ole intressiä. Siksi tehokkaan ja mielekkään oppimisen ehtona on, että aikuinen hyväksyy opittavat tehtävät. (Illeris 2004, 23.)

Aikuisiällä kouluttautumisen avulla köyhistä oloista nousseista yksilöistä tehtiin eräänlaisia oppimisen sankareita, joista on Suomessakin lukuisia esimerk- kejä. Malliesimerkki koulutukseen osallistuvasta aikuisesta on Hella Wuolijoen (Juhani Tervapään nimellä) kirjoittama tarina Juurakon Huldasta 1930-luvun loppupuolella.

Wuolijoki tyypitteli ilmiön yhden naisen tarinaksi 1930-luvun talouslaman ja työttömyyden vaivaamaa Suomea ja sen luokkaeroja kuvaavassa näytelmässään Juurakon Hulda. Helsingistä työtä hakemaan tullut oppimattoman pienviljelijäperheen tytär Hulda päätyy palvelustytöksi porvariskotiin, jossa käytyjä keskusteluja hänen on vaikea ymmärtää oudon sanaston vuoksi. Pikkuhiljaa Hulda alkaa opiskella työnsä ohessa ja kirjoittautuu lopulta Yhteiskunnalliseen korkeakouluun. Opintomenestys innostaa hänet pyrkimään eduskuntaan ajamaan köyhän väestön asiaa. Näytelmästä vuonna 1937 Valentin Vaalan ohjaaman ja kohua aiheuttaneen elokuvan nähtiin rikkovan rajoja ja horjuttavan luokkayhteiskunnan perustuksia. Kerrotaan tapauksista, joissa kotiapulaisia kiellettiin menemästä katsomaan elokuvaa huonojen vaikutteiden omaksumisen vuoksi. Palvelusväki haluttiin pitää "säädyssään". (Silvennoinen 2012, 214-315.)

Juurakon Huldan ajoista aikuisten kouluttautuminen on olennaisesti muuttunut elinkeino-, ammattija luokkarakenteen ja koulutusjärjestelmän sekä yleisen kulttuurin muutosten mukana. Suomessa aikuisille suunnattu koulutustarjonta on lisääntynyt muun muassa työvoimapoliittisen koulutuksen ja muiden aikuiskoulutusmuotojen kehittämisen seurauksena. Niin ikään opintotuki on huomattavasti parantunut viime vuosikymmenten aikana.

Uusliberaalien ajatusten innoittamina 1980-luvun puolivälissä koulutuspolitiikkaa alettiin suunnata tarjonnan sijaan enemmän kysynnästä käsin. Markkinaperiaatteiden ja -mekanismien käyttöönoton ohella oli merkittävää, että aikuiskoulutus nostettiin selvästi aiempaa näkyvämpään asemaan koulutuspolitiikassa. Aikuiskoulutuksesta haluttiin tehdä väline "hallitun rakennemuutoksen" toteuttamiseksi. Aikuisten kouluttamisesta tuli valtiollinen tehtävä, jona se kytkettiin tiiviisti talouteen ja työmarkkinoihin. Aikuiskoulutuksen yhteiskuntapoliittisen roolin vahvistuminen merkitsi ammatillisen aikuiskoulutuksen vahvistamista ja aikuisväestön kannustamista 
parantamaan ja uudistamaan työssä tarvittavia tietoja ja taitoja. (Pellinen 2001; Rinne \& Vanttaja 1999; Silvennoinen 2014.) Monet tutkijat ovat nähneet koulutuksen organisoinnin heijastelevan kehittyneiden teollisuusyhteiskuntien yleisempää siirtymää fordistisesta jälkifordistiseen tuotanto- ja kulutusmuotoon, tai modernista jälkimoderniin aikakauteen (ks. Ball 1990 ja 1994; Ward 2012).

Samaan aikaan uusliberalistisen politiikan globaalin levittäytymisen kanssa yhteiskuntatieteissä vahvistuivat teoriat entisten luokkakiinnikkeiden herpaantumisesta ja yksilöllistymisestä (Beck 1992; Beck \& Beck-Gernsheim 2002; Beck, Giddens \& Lash 1995) sekä aiempaa tietoisemmasta yksilöllisten identiteettien rakentamisesta (Giddens 1990; 1991).

Viime vuosikymmeninä OECD-maissa harjoitettu uusliberalistinen yhteiskunta- ja koulutuspolitiikka sekä individuaatiota ja identiteettityötä korostavat teoretisoinnit ovat ehkä yhdessä vahvistaneet käsitystä aikuiskoulutuksesta yksilöllisten valintojen kohteena. Aikuiskoulutus nähdään yksilön käyttöönottamana välineenä ja voimavarana sopeutua yhteiskunnalliseen muutokseen ja luoda itselle uusia mahdollisuuksia. Esimerkiksi Giddensin (1990; 1991) mukaan myöhäismodernina aikana ihmisillä on aiempaa enemmän käytössään tietoa ja resursseja ymmärtää omaa asemaansa, optioitaan ja elämänvalintojaan. He ovat myös entistä kykenevämpiä ja vapaampia, paitsi tulkitsemaan tilannettaan, myös rakentamaan itseään yksilönä ja omaa tulevaisuuttaan.

Aikuiskoulutustarjonnan ja -muotojen kehittämisen myötä osallistuminen koulutukseen aikuisiällä on laajentunut huomattavasti ja siitä on tullut "normaali" osa elämänkulkua. Normalisoitumisella on myös kääntöpuoli: "normaali" sisältää ajatuksen hyväksyttävästä ja toivottavasta, mutta myös epänormaalista ja ei-toivottavasta vajavaisuudesta (ks. Silvennoinen 2012). Koulutukseen osallistumisen normalisoituminen merkitsee myös lisääntynyttä kulttuurista painetta kouluttautumiseen, mikä näkyy kahdella tavalla.

Ensinnäkin, aikuiskoulutukseen on kehkeytynyt koulutusmuotoja, joihin osallistuminen ei ole yksiselitteisesti vapaaehtoista. Esimerkiksi työvoimahal- linnon osoittamasta työvoimapoliittisesta koulutuksesta kieltäytyminen on vahvasti sanktioitu. Koulutusmuotoon osallistuneiden määrä on suuri, kun otetaan huomioon kurssien verraten pitkä kesto: 2000-luvulla vuotuiset aloittajamäärät ovat vaihdelleet 55000 ja 85000 henkilön välillä (TEM 2008; TEM 2014). Työttömälle työvoimakoulutukseen osallistuminen on velvoite, vaikka suoranainen pakottaminen kurssille olisikin harvinaista.

Toinen laaja koulutusmuoto, johon osallistuminen ei ole yksiselitteisesti vapaaehtoista, on työnantajan kustantama henkilöstökoulutus. Suomessa henkilöstökoulutukseen osallistuu yli miljoona palkansaajaa vuosittain (Lyly-Yrjänäinen 2014; Niemi ym. 2014). Aloite henkilöstökoulutukseen osallistumisesta tulee usein esimieheltä tai työnjohdolta. Se on monilla työpaikoilla "tarjous, josta ei voi kieltäytyä", mikäli henkilö haluaa antaa itsestään kehityskelpoisen ja työhönsä sitoutuneen työntekijän kuvan (Järvensivu \& Koski 2012). Työntekijän kannattaa kouluttautua työnantajan kustannuksella mahdollisimman paljon, jotta työnantajalle ei olisi kannattavaa irtisanoa häntä. Joissakin ammateissa (esimerkiksi sosiaali- ja terveysalalla ja opetustoimessa) henkilöstön kouluttaminen on lakisääteistä.

Toiseksi, ylikansallisen elinikäisen oppimisen politiikan vahvistamisen myötä sosiologisessa tutkimuksessa on alettu tarkastella aikuisväestön koulutuksen lisäämispyrkimyksiä foucault'laisen hallinnan analytiikan näkökulmasta (Foucault 1991; 2010; Kaisto \& Pyykkönen 2011; Rose 1999; Silvennoinen 2002). Tätä nykyä elinikäinen oppiminen koskettaa kaikkia ihmisiä iästä ja asemasta riippumatta. Muiden muassa Euroopan unionin ja OECD:n voimakkaasti ajama elinikäisen oppimisen ideologia on jo muuttunut eräänlaiseksi itsestäänselvyydeksi, joka muokkaa subjektiviteettia uusiksi (Kinnari \& Silvennoinen 2015). Samalla kun nämä ylikansalliset toimijat suosittavat hallituksia lisäämään aikuisväestön koulutusta, niiden edustama näennäisesti epäpoliittinen ideologia tuottaa ja ylläpitää käsitystä uudenlaisesta muutoksiin sopeutuvasta ja autonomisesti itseään kehittävästä kansalaisesta. (Fejes 2010; Nicoll \& Fejes 2008; Olsen 2008.) 
Elinikäisen oppimisen ideologiat sisältävät aina käsityksen siitä, millainen yksilön tulisi olla ja miten hänen tulisi annetuissa olosuhteissa toimia (ks. Silvennoinen 2012). Nykyisin perusteluna ovat ennen muuta globaalin kilpailun sanelemat "taloudelliset realiteetit". EU:n kaltaisten ylikansallisten toimijoiden ja yksittäisen kansalaisen intressit elinikäisen oppimisen ajatusten toteuttamiseksi ovat monien koulutustutkijoiden mukaan kaukana toisistaan (esim. Borg \& Mayo 2005; Centano 2011; Dehmel 2006). Lissabonin strategian tavoite maailman kilpailukykyisimmän tietoon perustuvan talousalueen luomisesta ei motivoi oman toimeentulonsa ja työllisyytensä kanssa kamppailevaa kansalaista koulutettavaksi, kuten Gert Biesta (2006) asian muotoilee.

Aikuiskoulutusmarkkinat toimijoineen määrittävät vahvasti koulutukseen osallistumista eri maissa. Osallistumiserot ovat suuret (OECD 2003 ja 2013; Eurydice 2015). Maiden väliset erot aikuiskoulutusjärjestelmissä, koulutuskulttuureissa ja työelämän oppimiskäytännöissä merkitsevät myös sitä, että yksilön "omaehtoisen" koulutuskysynnän merkitys vaihtelee olennaisesti maasta toiseen (ks. Desjardins \& Rubenson 2013).

Esimerkiksi Suomessa valtion sääntelyn vahvistuminen ja aikuiskoulutuksen ammatillistuminen ovat edenneet käsi kädessä. Valtiovalta on vahvistanut otettaan aikuiskoulutuksesta sitä mukaa kuin ammattitaitojen päivittämisen ja ammatillisen liikkuvuuden tarpeet ovat yhteiskunnassa lisääntyneet. Aikuiskoulutuksen eri muotoja on etenkin 1980-luvulta lähtien "oksastettu" osaksi varsinaista, muodollista koulutusjärjestelmää (Antikainen ym. 2014, 117-120).

Suomessa ja Pohjoismaissa aikuiskoulutus on kansainvälisesti vertaillen vahvasti institutionalisoitunut ja aikuisväestön osallistuminen koulutukseen yleistä (ks. Antikainen 2006a ja 2006b; Rubenson 2006). Vaikka osallistumisasteet ovatkin korkeat, myös Pohjoismaissa osallistumisen esteet koetaan yhtä vahvasti kuin Manner-Euroopan ja liberaalin hyvinvointivaltion maissa. Pohjoismainen hyvinvointivaltio näyttää kuitenkin muita järjestelmiä paremmin luovan osallistumisen esteitä ylittävää toimi- juutta (Rubenson \& Desjardins 2009; ks Antikainen 2011).

Valtiolle aikuiskoulutuksesta on tullut tärkeä työvoimapoliittinen väline, ja yrityksissä ja julkisorganisaatioissa siitä on tullut osa henkilöstön kehittämistä. Suomalaisessa aikuiskoulutuksessa muutos on merkinnyt ennen kaikkea sitä, että ammatillinen aikuiskoulutus on noussut vapaan sivistystyön opintojen rinnalle ja ohi. Entisaikojen tyyliin ihannoitu opintojen omaehtoisuus on saanut antaa tilaa työmarkkinoilta ja työelämästä tuleville vaatimuksille sekä velvoitteille tuottavan osaamisen ylläpitämisestä. Nykyisessä eurooppalaisessa oppimisyhteiskunnassa valtiolla - ja myös Euroopan unionilla - on tärkeä rooli ammatilliseen aikuiskoulutukseen osallistumisen edistäjänä.

\section{OSALLISTUMISMALLEISTA}

Tunnetuimmat aikuiskoulutukseen osallistumista jäsentämään rakennetut mallit ovat 1970- ja 1980-luvuilta. Tuolloin kehitellyissä malleissa on vahvasti mukana ajatus yksilön osallistumispäätöksestä, johon vaikuttavat koulutuksen tarve sekä oppimishalut ja -motivaatio. Niiden yksilökeskeisyys ja aikuiskoulutuksen erityisyyttä korostava luonne eivät kovin hyvin vastaa Suomen kaltaisen maan nykytodellisuutta.

Patricia Crossin (1981) muotoilemassa Chain of Response -mallissa osallistumiseen päätyminen etenee vaiheittain toisiaan seuraavien päätöksentekoprosessien kautta. Psykologiset tekijät ovat mallissa keskeisessä asemassa, ja lähtökohtana onkin yksilön käsitys itsestään oppijana, mikä vaikuttaa olennaisesti hänen asennoitumiseensa koulutukseen. Seuraavassa vaiheessa yksilö punnitsee odotuksiaan koulutusta kohtaan sekä osallistumisen tuottamaa (lisä)arvoa. Viimeisessä vaiheessa päätöksenteon pohjaksi asettuvat osallistumisen mahdollisuudet ja (situationaaliset, dispositionaaliset ja institutionaaliset) esteet sekä koulutustarjontaa koskeva informaatio. Osallistuminen edellyttää esteiden ylittämistä.

Muiden muassa Kjell Rubenson (1982; 2011; Rubenson \& Maret 2015) on useaan otteeseen kritisoinut osallistumistutkimuksen psykologisoivaa otetta. Rubensonin (1977; 1979; ks. myös Rubenson 2001) Expectancy Valence -mallissa osallistuminen 
ankkuroituu yksilön ja hänen ympäristönsä vuorovaikutukseen. Yksilötasolla aiemmat kokemukset koulutuksesta sekä yksilölliset tarpeet ja ominaisuudet ovat tärkeitä selittäviä tekijöitä. Yksilön ympäristössä puolestaan tärkeimpiä tekijöitä ovat yksilön oma hyvinvoinnin taso, viiteryhmä kulttuureineen ja arvostuksineen sekä vallitseva koulutustarjonta. Valence (valenssi) viittaa mallissa arvoon, jonka yksilö liittää osallistumiseen. Eri ihmiset arvottavat samaa koulutusta eri tavoin. Expectancy (odote) taas viittaa niihin toiveisiin tai tavoitteisiin, jotka yksilö osallistumiseen liittää. Tietyn arvoiseksi arvioituun koulutukseen asetetut toiveet saavat aikaan motivaation, joka suotuisissa oloissa toteutuu tosiasiallisena osallistumisena.

Jyri Manninen (2004a; 2004b; Manninen ym. 2003) korostaa kehittelemässään mallissa yksilölle muodostunutta mielikuvaa aikuiskoulutuksesta osallistumiseen houkuttavana tai sen esteenä. Mielikuvayhteiskunnassa kulutushyödykkeisiin liitetyillä imagoilla on tärkeä merkitys ostopäätöstä tehtäessä. Koulutuksen houkuttelevuutta voidaan Mannisen mukaan lisätä mielikuvia manipuloimalla.

Lukuisia osallistumismalleja ei ole tarpeen käydä tässä yksityiskohtaisesti läpi (ks. Baert ym. 2006; Boshier 1973; Cookson 1986; Courtney 1992; Darkenwald \& Merriam 1982). Eri alojen tutkijat ovat arvioineet niitä eri näkökulmista (esim. Boeren ym. 2010; Silva ym. 1998). Suomessa osallistumismalleja ovat eritelleet ja tyypitelleet Manninen (1989; 2004a) ja Rinne ym. (1992).

Vaikka emme tässä artikkelissa etsi "oikeaa" aikuiskoulutukseen osallistumisen mallia, haluamme korostaa osallistumistutkimuksessa muutamaa asiaa. Aikuiskoulutuksen painopiste on viime vuosikymmenten aikana olennaisesti siirtynyt puhtaan omaehtoisesta koulutuksesta työelämän vaatimuksista kumpuavaan ammatilliseen koulutukseen. Siksi aikuiskoulutukseen osallistumista on aiheellista tarkastella yhteydessä henkilöstön kehittämiseen ja työmarkkinoihin. On ehkä paradoksaalista, mutta yksilökohtaiset tarpeet ja yksilöpsykologiset motiivit eivät ole enää oppimisyhteiskunnassa yhtä merkittävässä asemassa kuin Juurakon Huldan aikaan.

Koulutustutkimuksissa motivaatio jaetaankin usein autonomiseen ja kontrolloituun motivaati- oon, tai sisäiseen (intrinsic) ja ulkoiseen (extrinsic) motivaation (esim. Ahmed \& Bruinsma 2006; Deci \& Ryan 2000; Rothes ym. 2014). Autonominen ja sisäinen motivaatio nousevat yksilön sisäisestä kiinnostuksesta koulutuksen sisältöä kohtaan (esimerkiksi halu oppia soittamaan pianoa), kun taas kontrolloitu ja ulkoinen motivaatio perustuvat koulutuksesta saatavaan palkintoon (palkankorotus, työpaikan vaihto, sanktioiden välttäminen). Jaottelu on lähinnä analyyttinen ja empiirisesti vaikea tehdä. Kyse on eräänlaisista puhtaaksi viljellyistä motivaatiotyypeistä. Elävässä elämässä "sisäiset" ja "ulkoiset" motiivit eivät ole subjektille itsellekään selkeästi toisistaan erillisiä. Aikuiskasvatuksessa jakoon sisältyy myös ideologinen ajatus "sisäisistä" motiiveista "ulkoisia" motiiveja arvokkaampina.

Nykypäivänä päätös koulutukseen osallistumisesta ei ole vain yksilön oma tai puhtaasti "sisäisiin" motiiveihin perustuva. Osallistuminen juontaa juurensa entistä useammin työorganisaatioiden ja työvoimaviranomaisten päätöksiin ja aloitteisiin (Desjardins \& Rubenson 2013). Kun esimerkiksi puolet maan työvoimasta osallistuu koulutukseen työnantajan kustantamana, koulutuksesta on tullut jokseenkin arkipäiväinen osa työntekoa. Toki työelämässä jaossa olevan koulutuksen määrä vaihtelee huomattavasti hierarkiatasoittain, mikä kytkee koulutuksen kiinteästi yhteiskunnan luokkarakenteeseen, osaksi yleisempää voimavarojen (pääomien) jakojärjestelmää.

Henkilöstökoulutukseen osallistumisen rutinoitumisen vuoksi koulutukseen osallistuminen ei edellytä erityistä motivaatiota, tiedonjanoista innostusta, koettua koulutustarvetta tai harkintaa ja hyötyjen puntarointia. Monissa tehtävissä ja organisaatioissa yhden tai muutaman päivän koulutusjaksot niin sanotusti "kuuluvat asiaan”. Esimerkiksi sosiaali- ja terveydenhoidon alalla toimivien täydennyskoulutukseen osallistuminen on lakisääteistä (ks. SA1194/2003).

Toinen olennainen asia, joka on syytä ottaa huomioon osallistumista selitettäessä, on yleinen keskiluokkaistuminen. Keskiluokkaisissa asemissa kouluttautuminen on osa elämäntapaa. Aikuisten kouluttautuminen ja opinnot sekä osallistumismotivaatio on paikallaan asettaa erilaisissa elämäpiireissä elävi- 
en ihmisten sosiokulttuurisiin yhteyksiin. Siinä missä Courtney (1992) näkee aikuiskoulutukseen osallistumisen yhtenä sosiaalisen osallistumisen muotona, Risto Rinne ym. (1992, 33) esittävät, että "bourdieulaisittain aikuiskoulutukseen osallistumista voitaisiinkin tarkastella 'kulttuurin kuluttamisen yhtenä muotona', jonka sosiaalinen statusarvo ja rooli kulttuuripääoman muodostajana saattaa olla varsin merkittäväkin".

Sekä Crossin että Rubensonin mallissa otetaan esille yksilön osallistumiselle antama arvo liitettynä koulutukselta odotettavaan lupaukseen, hyötyyn tai lisäarvoon (ks. myös Boeren ym. 2012). Kun arvoa ja odotuksia tarkastellaan yksilön konkreettisessa elämäntilanteessa, käy ilmeiseksi, että niin arvot kuin odotukset määrittyvät olennaisesti yhteiskuntaluokasta ja taloudellisista ja kulttuurisista voimavaroista, pääomista käsin (Bourdieu 1984; Bourdieu \& Wacquant 1992).

Koulutusta koskevat arvostukset, asenteet, motivaatio, kulttuuriset itsestään selvyydet eivät ole satunnaisesti yksilökohtaisia, vaan noudattavat tiettyjä sosioekonomiseen asemaan perustuvia säännönmukaisuuksia. Osallistumismalleissa tulisi ottaa lähtökohdaksi se, että eri yhteiskuntaluokille ominaisissa kulttuureissa aktiviteetteja ja ajankäyttöä koskevat preferenssit eroavat olennaisesti toisistaan (ks. Nesbit 2005 ja 2011; Rubenson 2005; myös Antikainen 2009; Antikainen \& Huusko 2011). Luokkakulttuurit ovat edelleen tärkeä koulutukseen suhtautumiseen vaikuttava tekijä (Ball 2003; Savage 2000; Skeggs 2004). Preferensseihin kasvetaan, niitä ei valita tai vaihdeta mielivaltaisesti. Toisaalta osallistumista on syytä tarkastella myös tarjonnan suunnasta: työn organisointiin liittyen ja työnantajan henkilöstöryhmittäin eriytyvien koulutusintressien vuoksi itsensä kehittämisen mahdollisuudet ovat keskiluokkaisissa asemissa selvästi paremmat kuin työntekijäasemissa (Boudard \& Rubenson 2003; Silvennoinen \& Lindberg 2015).

Aikuiskoulutuksen kenttä ja käytännöt ovat esimerkiksi nyky-Suomessa niin eriytyneet, että osallistumisen selittäminen yhdellä osallistumismallilla ei ehkä olekaan mielekästä. Kansalaisopistojen posliininmaalauskurssi, kasvatustieteen tutkijoiden ja opettajien tieteellinen konferenssi, pitkäaikaistyöttö- mien elämänhallinta- ja urasuunnittelukurssi, työpaikan työsuojeluvaltuutetun ay-koulutukset, yksityisen tanssikoulun sambakurssi, sosiaali- ja terveydenhoitoalan henkilöstön lakisääteinen täydennyskoulutus tai luokkahitsauskoulutukset kulkevat kaikki aikuiskoulutuksen nimikkeen alla, mutta ovat toimintana hyvin erilaisia. Osallistumismalleissa on ehkä liikaakin tarkasteltu aikuiskoulutukseksi nimettyä toimintaa (ja siihen osallistumista) yhtenäisenä ilmiönä.

"Perinteiset" osallistumismallit sopivat paremmin niin kutsutun omaehtoisen aikuiskoulutuksen jäsentämiseen. Tällaisia ovat esimerkiksi monet vapaan sivistystyön opinnot tai vaikkapa ylioppilastutkinnon suorittaminen aikuisiällä. Edelleenkin aikuiskoulutus tarjoaa esimerkiksi nuoruusiän koulutuksessa heikosti menestyneelle yksilölle "toisen mahdollisuuden", mutta koko aikuiskoulutuksen volyymistä perusasteen varassa olevien aikuisten suorittamat ammatilliset tutkinnot edustavat verraten pientä osaa.

\section{OSALLISTUMISTUTKIMUKSET SUOMESSA}

Tilastokeskus on toteuttanut aikuisväestön kattavaa tutkimusta aikuiskoulutukseen osallistumisesta vuodesta 1980 alkaen. Vuodesta 1990 lähtien tutkimus on toistettu noin viiden vuoden välein. Vuosien 2006 ja 2012 tiedonkeruut ovat osa Euroopan unionin aikuiskoulutustutkimusta, jota koordinoi EU:n tilastovirasto Eurostat. Seuraava tiedonkeruu on suunniteltu vuodelle 2016.

Tilastokeskuksen vuonna 1980 aloittamaa tutkimussarjaa edelsi Heikki Lehtosen ja Jukka Tuomiston vuonna 1972 tekemä postikysely aikuiskoulutukseen osallistumisesta (ks. Lehtonen \& Tuomisto 1972 ja 1974). Tuolloin kohdejoukko olivat 16-64-vuotiaat ja otoksen koko 1440. Sitä voidaan pitää suomalaisen aikuiskoulutuksen osallistumistutkimuksen pioneerina. Näillä aineistoilla saadaan aikuiskoulutukseen osallistumisesta piirrettyä jo lähes 40 vuotta kuvaava aikajana (kuvio 1; ks. myös Silvennoinen 2013).

Ammatillisen aikuiskoulutuksen yleistyminen ja institutionalisoituminen näkyvät selvästi koulutukseen osallistumisessa. Lehtosen ja Tuomiston (1974) tutkimuksen mukaan 1970-luvun alussa 4 prosenttia aikuisväestöstä osallistui ammatilliseen ja 


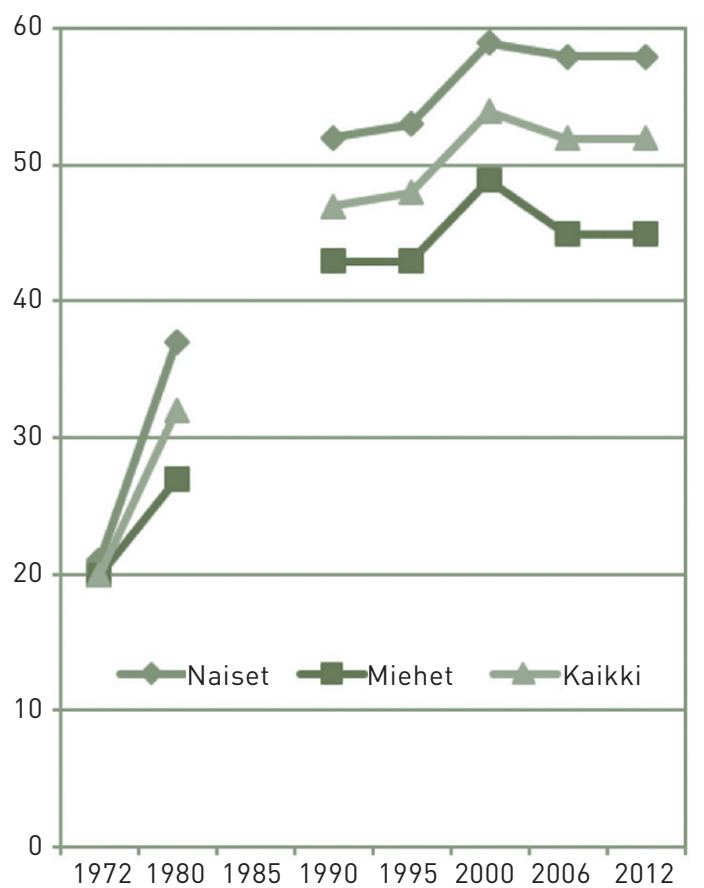

Kuvio 1. Aikuiskoulutukseen osallistuminen Suomessa sukupuolen mukaan vuosina 1972, 1980, 1990, 1995, 2000, 2006 ja 2012, \% (vuosi 1972: osuus 16-64-vuotiaasta väestöstä; muut vuodet: osuus 18-64-vuotiaasta väestöstä).

Lähteet: Lehtonen \& Tuomisto 1974; Niemi ym. 2014.

12 prosenttia yleissivistävään koulutukseen. Vuonna 1980 ammatilliseen aikuiskoulutukseen osallistuvia oli 24 prosenttia ja yleissivistävään koulutukseen 17 prosenttia aikuisista (Havén \& Syvänperä 1983).

Vuonna 1990 ammatilliseen aikuiskoulutukseen osallistuminen kohosi 44 prosenttiin, kun yleissivistävään koulutukseen (eli pääasiassa vapaan sivistystyön opintoihin) osallistuminen sen sijaan pysytteli 18 prosentissa. Vuoden 1995 aikuiskoulutustutkimuksen mukaan osallistuminen oli samalla tasolla.

Vuonna 2006 ammatilliseen koulutukseen osallistuminen oli noussut 51 prosenttiin yleissivistävään koulutuksen osallistumisen pysyessä entisellä tasolla. Työelämän muutoksen vuoksi entistä tärkeämmäksi nousseet ammattitaidon päivittämisvaatimukset ja sitä seurannut aikuiskoulutuksen ammatillistuminen määrittävät aikuiskoulutuspolitiikkaa 2010-luvulla aivan toisella tavalla kuin esimerkiksi 1970-luvulla, puhumattakaan sitä edeltäneestä ajasta.

Vuoteen 2000 jatkunut osallistumisosuuksien kasvu taittui 2000-luvun alkuvuosina (kuvio 1). Vuonna 2000 naisista osallistui aikuiskoulutukseen 59 ja miehistä 49 prosenttia. Sen jälkeen ero hieman kasvoi, ja naisten osuudet ovat pysytelleet 58 prosentissa ja miesten 45 prosentissa. Onko aikuiskoulutukseen osallistuminen saavuttanut jonkinlaisen saturaatiotason, jonka jälkeen osallistumista ei saada lisääntymään vanhoilla keinoilla?

Vuoden 2012 tulosten mukaan aikuiskoulutuspäivien lukumäärä on vähentynyt suorastaan jyrkästi vuoden 2000 tasosta. Miesten koulutuspäivien määrä on vähentynyt 10,2 päivästä 7,2 päivään ja naisten 15,1 päivästä 10,7 päivään. Vuosien 2006 ja 2012 välisenä aikana koulutuspäivien määrä on vähentynyt erityisen paljon naisilla. Iän mukaisessa tarkastelussa paljastuu toinen mielenkiintoinen muutos: koulutuspäivät ovat erityisesti vähentyneet nuorimmissa ikäryhmissä. Sen sijaan 35-44-vuotiaiden, 45-54-vuotiaiden ja 55-64-vuotiaiden ryhmissä koulutuspäivien lukumäärä on edelleen vuoden 2000 tasolla. (Silvennoinen 2013.)

\section{AIKUISKOULUTUSTUTKIMUS 2012 -AINEISTO}

Aikuiskoulutustutkimus 2012 (AKU2012) on otantatutkimus, jonka perusjoukkona ovat Suomessa pysyvästi asuvat 18-69-vuotiaat. Vuonna 2012 tutkimuksen otos oli 6149 henkilöä. Aineistonkeruun ensisijaisena menetelmänä oli tietokoneavusteinen käyntihaastattelu. Kadon pienentämiseksi vuoden 2012 tutkimukseen otettiin toiseksi tiedonkeruumenetelmäksi puhelinhaastattelu, jota käytettiin tilanteissa, joissa haastateltava ei suostunut käyntihaastatteluun. Toteutunut otoskoko on 4114 henkilöä ja vastausosuus 68 prosenttia. Aineiston avulla saadaan kokonaiskuva aikuiskoulutuksen volyymistä eri väestönosissa. (Tilastokeskus 2013; aineistosta ks. Niemi ym. 2014.)

AKU2012-tutkimuksessa aikuiskoulutuksella tarkoitetaan "aikuisille järjestettyjä ohjattuja oppimistilaisuuksia". Tutkimuksessa aikuiskoulutus on rajattu koulutusta antavan organisaation (oppilaitoksen, 
koulutusyrityksen tms. koulutuksen järjestäjän) perusteella. Annetun koulutuksen on oltava kestoltaan vähintään kuusi tuntia. Haastatelluilta kysyttiin yksityiskohtaiset tiedot enintään yhdestätoista heidän edeltävän 12 kuukauden aikana osallistumastaan koulutuksesta (kurssista tai muusta koulutustapahtumasta). Jokaisesta koulutuksesta tiedetään kesto, järjestäjä, koulutusorganisaatio, sisältö ja opiskelumuoto. Lisäksi haastatelluilta kysyttiin käydyn koulutuksen ohella tietoja muun muassa opintojen ohjauksesta, etäopiskelusta, ajankäytöstä, kustannuksista, osallistumisen syistä, tyytyväisyydestä sekä koulutuksessa saatujen taitojen käytöstä ja vaikutuksista työuralle.

Koulutukset on jaettu AKU2012-aineistossa kolmeen tyyppiin: (1) työhön tai ammattiin liittyvät koulutukset, (2) henkilöstökoulutukset sekä (3) muut kuin työhön tai ammattiin liittyvät koulutukset. Aineiston sisältämät tiedot mahdollistavat tarkemmin määriteltyjen aikuiskoulutustyyppien muodostamisen kuin aineiston valmiiksi sisältämät kolme tyyppiä. Tämän artikkelin tarpeisiin muodostamamme aikuiskoulutustyypit eivät ole keskenään päällekkäisiä. Muodostettavat koulutustyypit ovat järjestäjän ja koulutusmuodon suhteen yksiselitteisiä, mutta kuitenkin samalla riittävän yleisiä, jotta niiden volyymiä on mielekästä tarkastella väestötasolla.

\section{OSALLISTUMISEN JAKAUTUMINEN KOULUTUSTYYPPEIHIN}

Muodostamme aineiston sisältämistä koulutuksista kahdeksan aikuiskoulutustyyppiä, joihin osallistumista tarkastelemme (ks. kuvio 2). Tyyppien muodostamisessa keskeinen huomioon otettava seikka on se, että useat koulutusorganisaatiot tarjoavat monenlaista koulutusta. Erityisesti järjestöt, liitot ja yhdistykset tarjoavat niin työhön tai ammattiin liittyvää kuin harrasteperustaista koulutusta. Myös jotkut vapaan sivistystyön organisaatiot, jotka tarjoavat pääasiassa harrasteperustaista (tai "yleissivistävää") koulutusta, tarjoavat jonkin verran myös ammatillista koulutusta.

Jokainen aineiston sisältämä yksittäinen koulutus on luokiteltu kuuluvaksi johonkin kahdeksasta aikuiskoulutustyypistä seuraavien neljän kriteerin pe- rusteella: koulutuksen funktio (työhön tai ammattiin liittyvä koulutus erotettuna muun tyyppisestä koulutuksesta), koulutuksen kustantaja (työantaja tai jokin muu taho), koulutusorganisaatio (ks. liite 1) sekä koulutusmuoto (formaali tai non-normaali). ${ }^{1}$ Muodostetut kahdeksan aikuiskoulutustyyppiä ovat sikäli yksiselitteisiä, että jokainen aineiston sisältämä kurssi voi kuulua vain yhteen niistä (kuvio 2 sisältää yhden aikuiskoulutustyypin, jolle ei ole AKU2012aineistoissa empiiristä vastinetta, tyyppi I).

AKU2012 -aineiston valmiiksi sisältämässä luokituksessa "henkilöstökoulutukseksi" on luokiteltu kaikki sellaiset työhön tai ammattiin liittyvät koulutukset, jotka ovat osittain tai kokonaan työnantajan kustantamia. "Työhön tai ammattiin liittyvä koulutus" ja "henkilöstökoulutus" eivät siten ole aineiston alkuperäisessä luokituksessa varsinaisesti erillisiä aikuiskoulutustyyppejä, vaan "henkilöstökoulutus" ainoastaan viittaa tietyt kriteerit täyttäviin (so. työnantajan kustantamiin) työhön tai ammattiin liittyviin kursseihin. Henkilöstökoulutus on työhön tai ammattiin liittyvän koulutuksen alakategoria paitsi määritelmältään myös kohderyhmältään: työhön tai ammattiin liittyvän koulutuksen kohderyhmänä ovat kaikki työvoimaan kuuluvat kun taas henkilöstökoulutuksen kohderyhmän muodostavat palkansaajat.

Muodostetussa luokituksessa työhön tai ammattiin liittyvä koulutus jaetaan kuuteen tyyppiin, jotka eivät ole keskenään päällekkäisiä. Ensinnäkin henkilöstökoulutus on jaettu koulutusorganisaation perusteella kahteen tyyppiin: työpaikalla tapahtuvaan "työpaikkakoulutukseen" sekä työpaikan ulkopuolella tapahtuvaan "ulkoiseen henkilöstökoulutukseen". On tärkeää huomata, että nyt muodostetussa luokituksessa "henkilöstökoulutus" ja "työpaikkakoulutus" eivät ole synonyymejä, sillä kaiken työpaikoilla tapahtuvan opastuksen ja koulutuksen ei välttämättä tarvitse olla työnantajan kustantamaa, eli kaikki "työ-

1. Tilastokeskuksen soveltamassa luokituksessa "formaali koulutus" tarkoittaa koulutusjärjestelmän antamaa koulutusta, joka tähtää tutkinnon suorittamiseen ja "non-formaali koulutus" kurssimuotoista, muuta kuin koulujärjestelmän mukaiseen tutkintoon johtavaa koulutusta. 


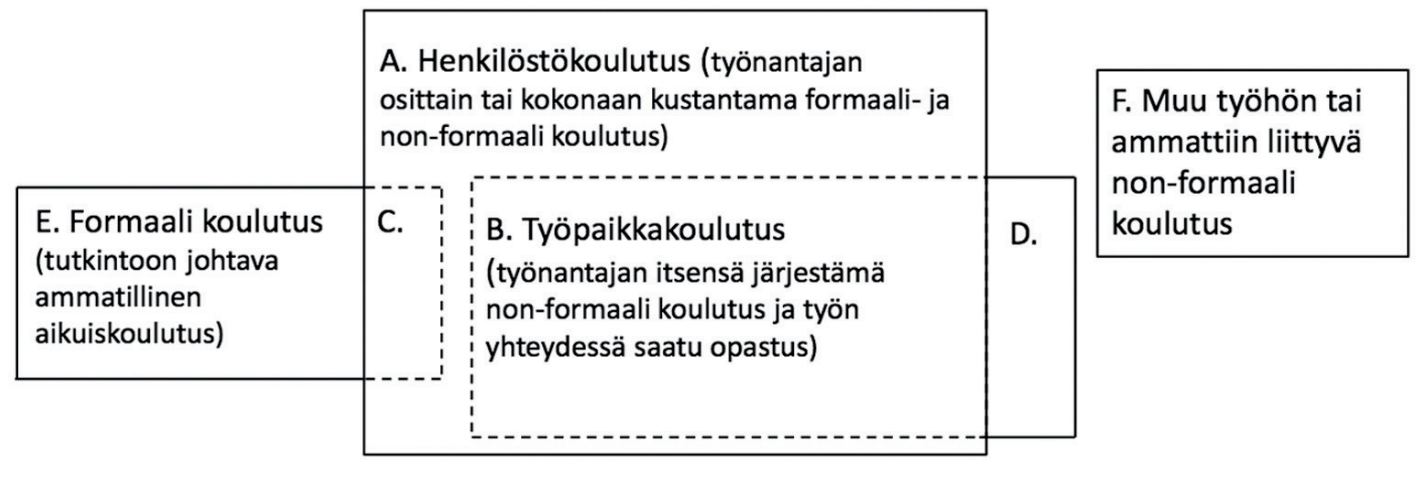

Koulutuksen funktio: muu kuin työhön tai ammattiin liittyvä ("harrasteperustainen") koulutus

\begin{tabular}{|l|}
\hline G. Vapaan sivistystyön (VST) \\
koulutusorganisaatiot \\
(formaali ja non-formaali \\
koulutus)
\end{tabular}

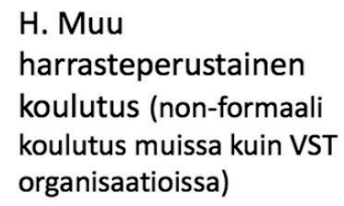

H. Muu harrasteperustainen koulutus (non-formaali koulutus muissa kuin VST organisaatioissa)

\section{Formaali koulutus (muut kuin VST organisaatiot)}

Kuvio 2. AKU2012-aineistossa muodostetut aikuiskoulutustyypit.

A: ulkoinen henkilöstökoulutus: muualla kuin työpaikalla tapahtuva työnantajan kustantama nonformaali koulutus (nelikulmio A poisluettuna sen sisällä olevat alueet B ja C); tyypillisesti koulutusyritykset ja -keskukset, järjestöt, liitot ja yhdistykset; konferenssit ja seminaarit yms.

B: työpaikkakoulutus: työpaikalla tapahtuva työnantajan kustantama non-formaali koulutus; tyypillisesti työnantajan järjestämä koulutus, opastus työn yhteydessä.

C: formaali henkilöstökoulutus: ammatillisen tutkinnon suorittaminen osittain tai kokonaan työantajan tukemana; tyypillisesti oppisopimuskoulutus, tutkinnon osat.

D: muu työpaikoilla tapahtuva non-formaali koulutus: kaikki sellainen työpaikalla tapahtuva nonformaali koulutus, joka ei ole työnantajan kustantamaa.

E: työhön tai ammattiin liittyvä formaali koulutus: ammatillisen aikuiskoulutustutkinnon suorittaminen; tyypillisesti: aikuisille suunnatut formaalit koulutusohjelmat ammattikorkeakouluissa tai ammatillisissa oppilaitoksissa, oppisopimuskoulutus, aikuis- ja iltalukiot.
F: muualla kuin työpaikoilla tapahtuva non-formaali koulutus: kaikki työhön tai ammattiin liittyvä non-formaali koulutus, joka ei ole työnantajan kustantamaa ja joka ei tapahdu työpaikoilla; tyypillisesti koulutusyritykset ja-keskukset, konferenssit ja seminaarit sekä järjestöt, liitot ja yhdistykset. G: vapaan sivistystyön (VST) koulutusorganisaatioiden antama non-formaali (G1) ja formaali (G2) koulutus: VST-koulutusorganisaatiot, kansanopistot, kansalaisopistot, opintokeskukset, liikunnan koulutuskeskukset ja kesäyliopistot. $\mathrm{H}$ : harrasteperustainen opiskelu muissa kuin vapaan sivistystyön koulutusorganisaatioissa: $\mathrm{mm}$. musiikkioppilaitokset, kuvataide-, käsityö- ja tanssikoulut sekä järjestöt, liitot ja yhdistykset.

I: "Harrasteperustainen formaali koulutus". Tyypille ei empiiristä vastinetta AKU2012-aineistossa. 
paikkakoulutus" ei välttämättä ole "henkilöstökoulutusta”, ja päinvastoin.

Kaikki tutkintoon johtavat työhön tai ammattiin liittyvät koulutukset, jotka eivät ole työnantajan kustantamia, edustavat muodostetussa luokituksessa tyyppiä "työhön tai ammattiin liittyvä formaali koulutus". Se käsittää ammatillisten oppilaitosten ja ammattikorkeakoulujen aikuisille suunnatun koulutuksen, oppisopimuskoulutuksen sekä aikuis- ja iltalukiot. Tutkintoon johtavaa ammatillista aikuiskoulutusta on tarjolla pienemmässä määrin myös vapaan sivistystyön piirissä. Työantajan tukema ammatillisen aikuiskoulutustutkinnon suorittaminen (erit. oppisopimuskoulutus) on luettu kuuluvaksi tyyppiin "formaali henkilöstökoulutus". Muodostettu luokitus sisältää näin ollen kolme henkilöstökoulutustyyppiä (ulkoinen, formaali ja työpaikkakoulutus).

"Muualla kuin työpaikoilla tapahtuva non-formaali koulutus" käsittää kaiken sellaisen työhön tai ammattiin liittyvän non-formaalin koulutuksen, jolla ei ole suoranaista yhteyttä työnantajaan, eli jota ei voida lukea henkilöstökoulutukseksi tai työpaikkakoulutukseksi.

Kaikkea sellaista aikuiskoulutusta, jolla ei ole selkeää työhön tai ammattiin liittyvää funktiota, nimitetään tässä yksinkertaisesti "harrasteperustaiseksi koulutukseksi”. Suomessa harrasteperustaisen aikuiskoulutuksen kivijalan muodostaa vapaa sivistystyö (VST), jonka oppilaitokset ovat lainsäädännöllisesti erityisasemassa muihin harrasteperustaista aikuiskoulututusta antaviin organisaatioihin nähden. Vapaatavoitteisen tai harrasteperustaisen koulutuksen ohella VST-organisaatiot tarjoavat ammatillista koulutusta. Kansanopistoissa on harrasteperustaisten kurssien lisäksi mahdollista suorittaa myös ammatillisia perustutkintoja. Kesäyliopistot tarjoavat muun koulutuksen ohella ammatillista täydennyskoulutusta ja liikunnan koulutuskeskukset alansa ammatillista koulutusta.

AKU2012-aineistossa kaikki formaali eli koulutusjärjestelmän mukaiseen tutkintoon johtava koulutus on lähtökohtaisesti luokiteltu funktioltaan työhön tai ammattiin liittyväksi. Toisin sanoen, AKU2012-aineiston alkuperäisessä luokituksessa mikään tutkintoon johtava opiskelu ei ole harrasteperustaista. Tässä muodostetussa luokituksessa kaikki VST-organisaatioiden antama koulutus, ammatillisen pätevyyden antavat kurssit mukaan luettuina, edustavat harrasteperustaista aikuiskoulutustyyppiä. Tämä on perusteltua siitä syystä, että kaikki ammatillista koulutusta antavat VST-organisaatiot antavat samalla myös harrasteperustaista koulutusta ja ammatillisen koulutuksen volyymi on niissä vähäinen verrattuna harrasteperustaiseen koulutukseen, kuten myöhempi tilastollinen tarkastelu osoittaa.

AKU2012-aineiston tietojen avulla voidaan laskea, kuinka moneen kurssiin kyselyyn vastanneet 4114 henkilöä ovat yhteensä osallistuneet vuoden aikana ja kuinka monta koulutuspäivää kurssit ovat yhteensä kestäneet. Aineiston avulla on siten mahdollista arvioida, kuinka suuren osan kaikesta Suomessa vuoden aikana annetusta aikuiskoulutuksesta kukin yksittäinen aikuiskoulutustyyppi muodostaa niin suoritettujen kurssien kuin koulutuspäivien osalta.

Henkilöstökoulutus on selvästi yleisin aikuiskoulutustyyppi noin 66 prosentin osuudella kaikista vuotuisista aikuiskoulutuksista (kuvio 3). Volyymiltään toiseksi merkittävin tyyppi on VST-koulutus, jonka osuus kaikista koulutuksista on noin 14 prosenttia. Henkilöstökoulutus on myös koulutuspäivien osuudella mitattuna selvästi suurin aikuiskoulutustyyppi (kuvio 4). Työhön tai ammattiin liittyvät aikuiskoulutustyypit muodostavat yhdessä noin 78 prosenttia kaikista aikuiskoulutuksista, harrasteperustaisten tyyppien osuudeksi jäädessä loput noin 22 prosenttia - vastaavat osuudet koulutuspäivistä ovat noin 71 prosenttia ja 29 prosenttia.

Työpaikkakoulutus (tyyppi B) on sekä kursseina että koulutuspäivinä laskien selvästi suurin työhön tai ammattiin liittyvistä aikuiskoulutustyypeistä. Työpaikkakoulutus sekä kaksi muuta henkilöstökoulutustyyppiä (A ulkoinen ja C formaali) muodostavat yhteensä noin 85 prosenttia kaikista vuoden aikana olleista työhön tai ammattiin liittyvistä kursseista. Henkilöstökoulutuksen kolmen eri tyypin yhteenlaskettu osuus kaikista koulutuspäivistä on 58 prosenttia, eli 
(H) $9 \%$

(G) 14

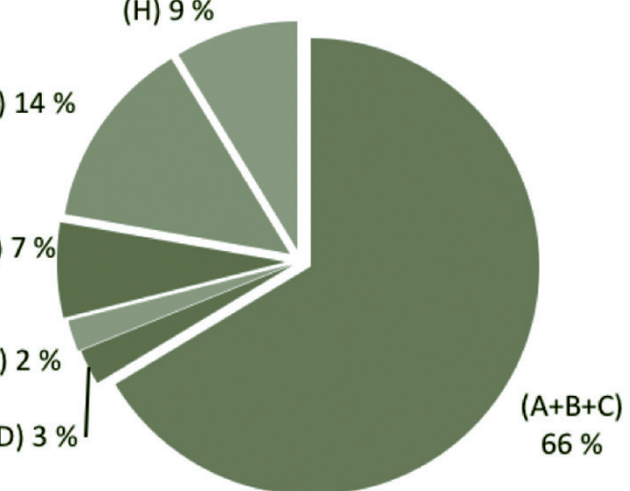

$A+B+C$. Henkilöstökoulutus

D. Muu työpaikoilla tapahtuva koulutus

E. Työhön tai ammattiin liittyvä formaali koulutus

F. Muu työhön tai ammattiin liittyvä koulutus

G. VST-koulutus

H. Muu harrasteperustainen koulutus
(G) 18

(H) $12 \%$

(F) $10 \%$

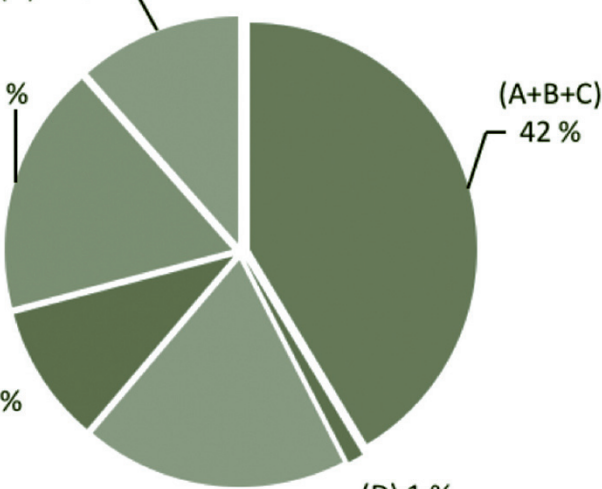

(E) $19 \%$

(D) $1 \%$

$A+B+C$. Henkilöstökoulutus

D. Muu työpaikoilla tapahtuva koulutus

E. Työhön tai ammattiin liittyvä formaali koulutus

F. Muu työhön tai ammattiin liittyvä koulutus

G. VST-koulutus

H. Muu harrasteperustainen koulutus

Kuvio 3. Aikuiskoulutustyypit:

Kuvio 4. Aikuiskoulutustyypit:

osuudet kursseista.

osuudet koulutuspäivistä.

Taulukko 1. Osallistuminen työhön tai ammattiin liittyvän aikuiskoulutuksen eri tyyppeihin.

Taulukon selitykset: \% = osallistumisaste; $k a$ = koulutuspäivien keskiarvo koulutukseen osallistuneille; oda = koulutuspäivien odotusarvo (koulutuspäivien keskiarvo kerrottuna osallistumisasteella). Perusjoukko: 18-64-vuotias työvoima (henkilöstökoulutusten osalta palkansaajat).

\begin{tabular}{|c|c|c|c|c|c|c|}
\hline & \multicolumn{2}{|c|}{$\begin{array}{c}(\mathrm{A}) \\
\text { Henkilöstökoulutus: } \\
\text { ulkoinen }\end{array}$} & \multicolumn{2}{|c|}{$\begin{array}{l}\text { (B) } \\
\text { Henkilöstökoulutus: } \\
\text { työpaikkakoulutus }\end{array}$} & \multicolumn{2}{|c|}{$\begin{array}{l}\text { (C) } \\
\begin{array}{l}\text { Henkilöstökoulutus: } \\
\text { formaali }\end{array}\end{array}$} \\
\hline & $\%$ & oda & $\%$ & oda & $\%$ & ka \\
\hline Koko perusjoukko & 22,7 & 1,3 & 48,5 & 2,7 & 2,9 & 30,3 \\
\hline Miehet & 22,2 & 1,2 & 44,1 & 2,4 & 2,1 & 22,9 \\
\hline Naiset & 23,2 & 1,5 & 52,8 & 3,0 & 3,7 & 34,8 \\
\hline Johtajat ja ylim. virkamiehet & 49,6 & 3,3 & 51,3 & 3,0 & 2,3 & - \\
\hline Erityisasiantuntijat & 37,1 & 2,5 & 57,5 & 3,5 & 2,3 & - \\
\hline Asiantuntijat & 26,3 & 1,7 & 57,8 & 3,8 & 4,7 & - \\
\hline Toimisto- ja asiakas-palveluyöntekijät & 21,4 & 0,7 & 45,3 & 4,1 & 2,7 & - \\
\hline Palvelu-, myynti- ja hoitotyöntekijät & 11,1 & 0,4 & 49,9 & 1,9 & 2,9 & - \\
\hline Rakennus-, korjaus- ja valmistustyöntekijät & 9,7 & 0,5 & 38,2 & 1,4 & 3,2 & - \\
\hline Prosessi- ja kuljetustyöntekijät & 13,1 & 0,6 & 32,6 & 1,2 & 1,6 & - \\
\hline Muut työntekijät & 6,1 & 0,3 & 23,8 & 0,8 & 2,5 & - \\
\hline
\end{tabular}


27 prosenttiyksikköä vähemmän verrattuna osuuteen kursseista. Formaalin aikuiskoulutuksen (tyyppi E) osuus kaikista työhön tai ammattiin liittyvistä kursseista on melko marginaalinen, mutta koulutuspäivistä se muodostaa neljäsosan. (Liitetaulukko 1 esittää kuuden työhön tai ammattiin liittyvän aikuiskoulutustyypin osuudet kaikista AKU2012-aineistossa kuvatuista työhön tai ammattiin liittyvistä aikuiskoulutuskursseista [3135 kpl] ja aikuiskoulutuspäivistä [19481 kpl]. Yhden aikuiskoulutuspäivän kesto on kuusi tuntia.)

Vapaan sivistystyön oppilaitosten non-formaalit koulutukset (tyyppi G1) muodostavat 60 prosenttia kaikista vuoden aikana suoritetuista harrasteperustaisista koulutuksista. Muiden kuin VST-organisaatioiden antamien koulutusten osuudeksi jää 40 prosenttia. Formaalin VST-koulutuksen (G2) osuus kaikesta harrasteperustaisesta koulutuksesta on marginaalinen; koulutuspäivistä laskien sen osuus on noin kuusi prosenttia. (Liitetaulukko 2 esittää harrasteperustaisten aikuiskoulutustyyppien prosenttiosuudet kaikista AKU2012-aineistossa kuvatuista harrasteperustaisista kursseista [895 kpl] ja kaikista harrasteperustaisista koulutuspäivistä [7701 kpl].)

\section{OSALLISTUMISASTEET KOULUTUSTYYPEITTÄIN}

Edellä muodostettua kahdeksaa aikuiskoulutustyyppiä käytetään seuraavassa osallistumisen analyysissä. Mitä eritellymmin aikuiskoulutukseen osallistumista analysoidaan koulutuksen tyypin mukaan, sitä tarkempi käsitys saadaan siitä, miten osallistuminen on taustatekijöistä riippuen eriytynyt juuri tietyn sisältöiseen koulutukseen. Usein ongelmaksi muodostuu kuitenkin se, että osallistujamäärät joihinkin aikuiskoulutustyyppeihin jäävät aineistoissa yksityiskohtaisen analyysin kannalta liian pieniksi. Näin on myös AKU2012-aineistoa käytettäessä.

Taulukko 1 esittää osallistumisasteet työhön tai ammattiin liittyviin aikuiskoulutustyyppeihin ja taulukko $\mathbf{2}$ harrasteperustaisiin aikuiskoulutustyyppeihin. Osallistumisasteen laskemisessa otetaan huomioon ainoastaan yksi osallistumiskerta kyseessä olevaan aikuiskoulutustyyppiin viimeksi kuluneen vuoden aikana (eli henkilön useampikertainen osallistuminen koulutustyypin koulutukseen ei nosta osallistumisastetta). Näin saadaan laskettua niin kutsuttu netto-osallistumisaste kullekin koulutustyypille.

Osallistumisasteen lisäksi taulukot 1 ja 2 esittävät aikuiskoulutustyypistä riippuen joko koulutuspäivien

\begin{tabular}{|c|c|c|c|c|c|c|c|c|c|}
\hline \multicolumn{2}{|c|}{$\begin{array}{l}\qquad A+B+C) \\
\text { Henkilöstökoulutus: } \\
\text { kaikki }\end{array}$} & \multicolumn{2}{|c|}{ (E) Formaali koulutus } & \multicolumn{2}{|c|}{$\begin{array}{l}\text { (D) Muu työpaikoilla } \\
\text { tapahtuva koulutus }\end{array}$} & \multicolumn{2}{|c|}{$\begin{array}{l}\text { (F) Muu non-formaali } \\
\text { koulutus }\end{array}$} & \multicolumn{2}{|c|}{ Kaikki } \\
\hline$\%$ & oda & $\%$ & ka & $\%$ & ka & $\%$ & ka & $\%$ & oda \\
\hline 58,1 & 4,7 & 2,8 & 66,6 & 2,7 & 4,0 & 6,6 & 18,0 & 53,0 & 6,6 \\
\hline 53,3 & 3,9 & 2,4 & 61,7 & 2,5 & 4,3 & 6,1 & 24,4 & 47,1 & 5,9 \\
\hline 62,8 & 5,5 & 3,3 & 70,7 & 2,9 & 3,5 & 7,1 & 11,9 & 59,8 & 7,6 \\
\hline 65,5 & 6,4 & 0,7 & - & 5,2 & - & 8,5 & - & 59,1 & 5,4 \\
\hline 70,7 & 6.7 & 2,4 & - & 1,6 & - & 8,3 & - & 70,6 & 8,2 \\
\hline 68,5 & 6,2 & 2,8 & - & 0,7 & - & 5,9 & - & 67,4 & 6,7 \\
\hline 56,0 & 5,5 & 1,7 & - & 0 & - & 3,0 & - & 56,2 & 5,8 \\
\hline 55,8 & 3,0 & 4,3 & - & 3,0 & - & 5,2 & - & 55,7 & 7,7 \\
\hline 44,6 & 2,7 & 2,8 & - & 1,0 & - & 2,6 & - & 43,0 & 3,7 \\
\hline 41,0 & 2,2 & 2,4 & - & 1,7 & - & 5,2 & - & 42,7 & 4,6 \\
\hline 29,4 & 2,0 & 0,7 & - & 0,0 & - & 1,1 & - & 30,1 & 2,5 \\
\hline
\end{tabular}




\begin{tabular}{|l|c|c|c|c|c|c|c|c|c|c|}
\hline & $\begin{array}{c}\text { (G1) non-formaali } \\
\text { vst }\end{array}$ & \multicolumn{2}{|c|}{ (G2) formaali vst } & \multicolumn{2}{|c|}{ (G) vst kaikki } & \multicolumn{2}{c|}{$\begin{array}{c}\text { (H) muu non- } \\
\text { formaali }\end{array}$} & \multicolumn{2}{c|}{ Kaikki } \\
\hline & $\%$ & ka & $\%$ & ka & $\%$ & ka & $\%$ & ka & $\%$ & oda \\
\hline Koko perusjoukko & 10,9 & 11,8 & 0,1 & - & 11,0 & 12,5 & 7,0 & 11,5 & 16,4 & 2,2 \\
\hline Miehet & 5,9 & 14,6 & 0,0 & - & 6,0 & 15,7 & 4,6 & 12,9 & 9,6 & 1,5 \\
\hline Naiset & 15,9 & 10,7 & 0,2 & - & 16,1 & 11,3 & 9,4 & 10,9 & 23,3 & 2,8 \\
\hline Yrittäjät & 10,3 & 10,2 & 0 & - & 10,3 & 10,2 & 5,4 & - & 14,4 & 1,6 \\
\hline YTH & 14,5 & 9,6 & 0 & - & 14,5 & 9,6 & 10,4 & 10,9 & 23,1 & 2,5 \\
\hline ATH & 12,7 & 10,3 & 0,2 & - & 12,9 & 10,5 & 7,2 & 6,1 & 19,0 & 1,8 \\
\hline Työntekijät & 6,1 & 7,9 & 0,2 & - & 6,3 & 11,0 & 3,3 & 6,7 & 8,7 & 0,9 \\
\hline Opiskelijat & 10,3 & 25,7 & 0,2 & - & 10,5 & 28,5 & 11,8 & 19,8 & 19,7 & 5,4 \\
\hline Eläkeläiset & 11,9 & 11,8 & 0 & - & 11,9 & 11,8 & 5,1 & 9,0 & 15,1 & 1,9 \\
\hline Muu & 10,3 & 10,0 & 0 & - & 10,3 & 10,0 & 7,9 & - & 15,9 & 2,6 \\
\hline
\end{tabular}

Taulukko 2. Osallistuminen harrasteperustaisen aikuiskoulutuksen eri tyyppeihin. Perusjoukko: koko väestö.

Taulukon selitykset: \% = osallistumisaste; $k a$ = koulutuspäivien keskiarvo koulutukseen osallistuneille; oda = koulutuspäivien odotusarvo (koulutuspäivien keskiarvo kerrottuna osallistumisasteella). Perusjoukko: 18-64-vuotias väestö.

odotusarvon (oda) tai keskiarvon (ka). Koulutuspäivien odotusarvo saadaan, kun koulutukseen osallistuneiden koulutuspäivien keskiarvo kerrotaan osallistumisasteella. Jos osallistumisaste on hyvin matala, ei koulutuspäivien odotusarvon laskemista voida pitää mielekkäänä. Rajana on käytetty 20 prosentin osallistumisastetta. Jos koulutustyyppiin osallistuneita on alle 20 prosenttia kohderyhmästä, on taulukoissa 1 ja 2 raportoitu koulutuspäivien odotusarvon sijaan koulutuspäivien keskiarvo koulutukseen osallistuneille. Taulukossa 1 työhön tai ammattiin liittyvään aikuiskoulutukseen osallistumista on tarkasteltu sukupuolen ja ammattiryhmän mukaan ja taulukossa 2 harrasteperustaiseen aikuiskoulutukseen osallistumista sukupuolen ja sosioekonomisen aseman mukaan.

Ammattiryhmien välinen eriytyminen on erityisen suurta henkilöstökoulutuksen eri tyyppeihin osallistumisessa (taulukko 1). Johtajien ja ylimpien virkamiesten osallistumisaste ulkoiseen henkilöstökoulutukseen $(49,6 \%)$ on noin viisinkertainen verrattuna esimerkiksi rakennus-, korjaus- ja valmistustyöntekijöiden osallistumisasteen (9,7 \%). Kun tarkastellaan osallistumista työpaikkakoulutukseen, on johtajien ja ylimpien virkamiesten osallistumisaste vain noin kaksinkertainen rakennus-, korjaus- ja valmistustyöntekijöihin verrattuna.

Taulukon 2 perusteella opiskelijoita lukuun ottamatta kaikki sosioekonomiset ryhmät osallistuvat enemmän VST-koulutukseen kuin muuhun harrasteperustaiseen koulutukseen. Ryhmien väliset suhteelliset erot ovat lähes samat, tarkasteltiin sitten VST-koulutusta tai muuta harrasteperustaista koulutusta. Toisin sanoen, ne sosioekonomiset ryhmät, jotka osallistuvat muita ryhmiä enemmän VST-koulutukseen, osallistuvat muita enemmän myös muuhun harrasteperustaiseen koulutukseen. Kuten edellä työhön tai ammattiin liittyvän koulutuksen osalta, myös harrasteperustaiseen koulutukseen osallistumisen tarkasteleminen koulutustyypeittäin tuo selvästi lisää informaatiota verrattuna siihen, että kaikkea harrasteperustaista koulutusta tarkasteltaisiin yhtenä kokonaisuutena.

Todennäköisyyttä osallistua aikuiskoulutukseen mallinnetaan lopuksi logistisen regression avulla erikseen jokaisen muodostetun kahdeksan aikuiskoulutustyypin osalta. AKU2012-aineistossa joihinkin tässä muodostettuihin aikuiskoulutustyyppeihin 


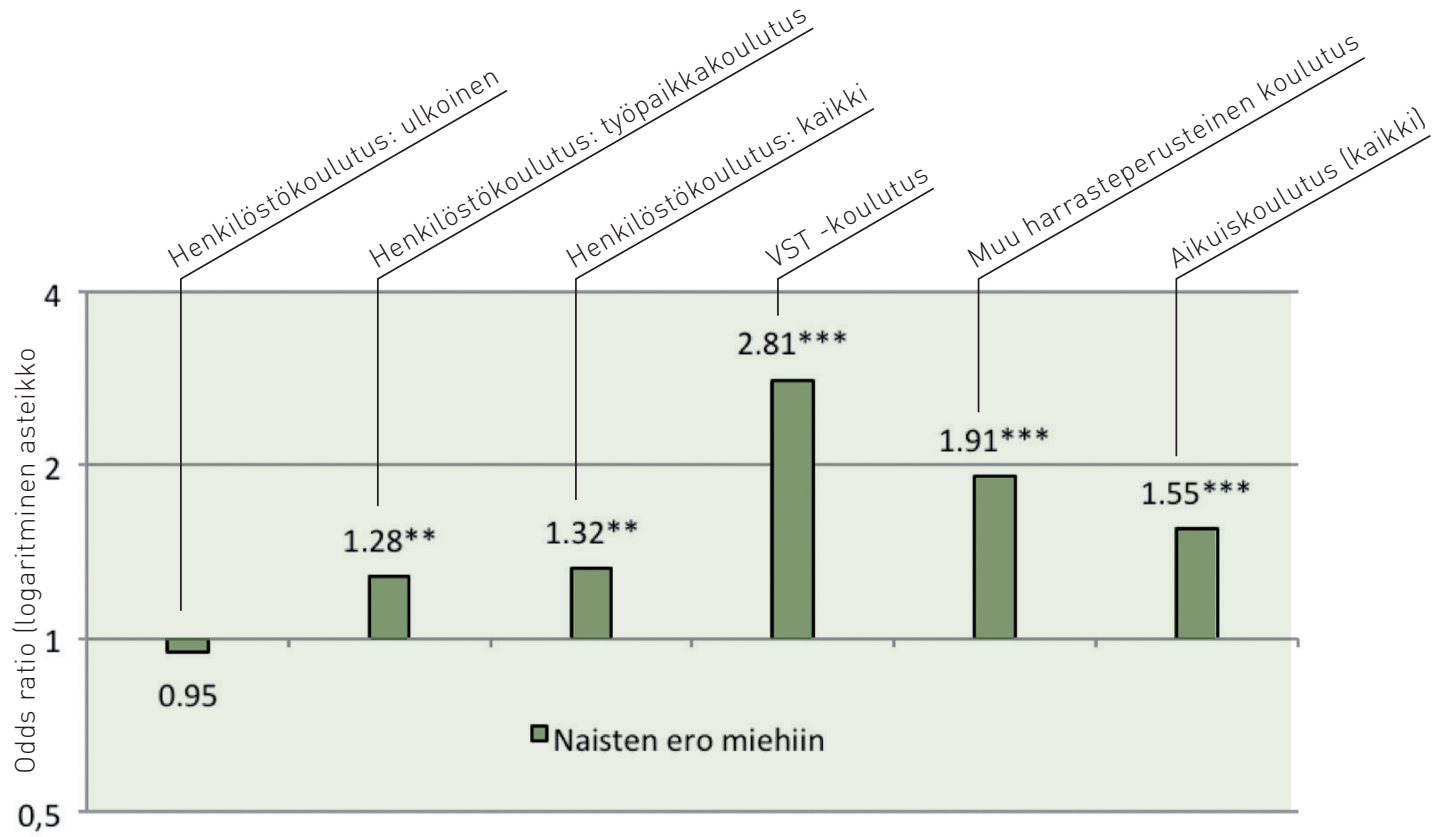

Kuvio 5. Sukupuolten väliset erot todennäköisyydessä osallistua aikuiskoulutukseen: logistisella regressiolla tuotetut odds ratio -estimaatit.

Kuvion selitykset. Regressiomalleissa on kontrolloitu sukupuoli, koulutustaso, ikä sekä ammatti tai sosio-ekonominen asema. Ero vertailuryhmään on tilastollisesti merkitsevä tasolla: ${ }^{*}=p<0.05 ;{ }^{* *}=p$-arvo $<0,01 ;{ }^{* * *}=p$-arvo $<0,001$.

osallistuneita on kuitenkin regressioanalyysin validiteetin kannalta liian vähän. Osallistujamäärältään liian pieniä tyyppejä ovat formaali VST-koulutus, formaali työhön tai ammattiin liittyvä koulutus, formaali henkilöstökoulutus sekä muu työpaikoilla tapahtuva opastus ja koulutus. Kaksi parhaiten osallistumista ennustavaa taustamuuttujaa ovat sukupuoli ja koulutustaso. Kuvio 5 esittää regressioanalyysin tulokset sukupuolten ja kuvio $\mathbf{6}$ koulutustasojen välisten erojen osalta.

Kun aikuiskoulutusta tarkastellaan yhtenä kokonaisuutena, on naisten osallistumistodennäköisyys (odds ratio) 1,55-kertainen miehiin verrattuna (ks. kuvio 5). Naisten ero miehiin vaihtelee kuitenkin voimakkaasti koulutuksen tyypin mukaan ollen suurin harrasteperustaisessa ja pienin työhön tai ammattiin liittyvässä koulutuksessa. Ulkoisen henkilöstökoulutuksen osalta naisten ja miesten osallistumistodennäköisyydet eivät eroa tilastollisesti merkitsevällä tasolla tosistaan. Ulkoinen henkilös- tökoulutus on siten tässä saatujen alustavien tulosten perusteella aikuiskoulutustyypeistä ainoa, johon osallistuminen ei ole eriytynyt sukupuolen mukaan. Voidaan sanoa myös, että se on aikuiskoulutustyypeistä "miehisintä".

Korkea-asteen koulutettujen todennäköisyys osallistua aikuiskoulutukseen on keskiasteen koulutettuihin verrattuna tilastollisesti merkitsevällä tasolla suurempi kaikissa tässä tarkastelluissa aikuiskoulutustyypeissä: ero on suurin harrasteperustaisessa koulutuksessa ja pienin työpaikkakoulutuksessa (ks. kuvio 6). Perusasteen koulutettujen osallistumistodennäköisyys on kaikissa aikuiskoulutustyypeissä matalin. Perusasteen koulutettujen ero keskiasteen koulutettuihin on tilastollisesti merkitsevä kuitenkin vain silloin, kun aikuiskoulutusta tarkastellaan yhtenä kokonaisuutena eikä koulutustyypin mukaan eriteltynä. 


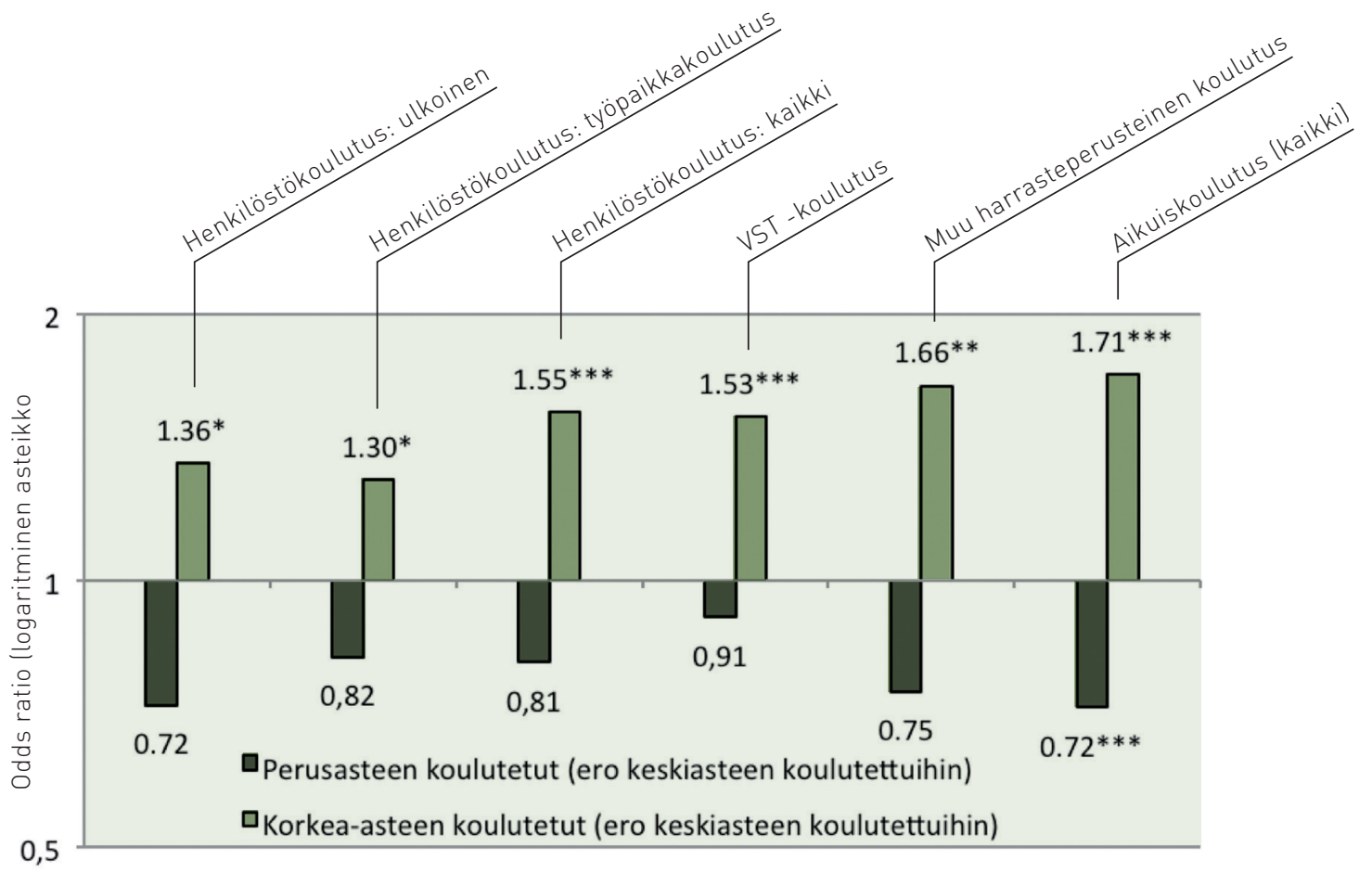

Kuvio 6. Koulutustasojen väliset erot todennäköisyydessä osallistua aikuiskoulutukseen: logistisella regressiolla tuotetut odds ratio -estimaatit.

Kuvion selitykset. Regressiomalleissa on kontrolloitu sukupuoli, koulutustaso, ikä sekä ammatti tai sosio-ekonominen asema. Ero vertailuryhmään on tilastollisesti merkitsevä tasolla: ${ }^{*}=p<0.05 ;{ }^{* *}=p$-arvo $<0,01 ;{ }^{* * *}=p$-arvo $<0,001$.

\section{LOPPUPÄÄTELMIÄ}

Olemme edellä tarkastelleet aikuiskoulutukseen osallistumista AKU2012-aineiston avulla. Se on kattavin käytössä oleva koko Suomen aikuisväestön kouluttautumista ja "koulutusaktiivisuutta" kuvaava aineisto. AKU2012-aineiston perusteella 71 prosenttia vuonna 2012 toteutuneista koulutuspäivistä oli työhön tai ammattiin liittyvää koulutusta. Osuudesta työnantajan kustantamaa henkilöstökoulutusta oli yli puolet. Käydyistä kursseista (tai koulutustapahtumista) yksistään työnantajan kustantamaa koulutusta oli peräti 66 prosenttia. Vapaan sivistystyön osuus kursseista oli 14 prosenttia.

Tulokset viittaavat selvästi siihen, että enemmistö aikuiskoulutuksesta on jotain muuta kuin perinteisesti ymmärrettyä "omaehtoista" itsensä kehittämistä.

\section{KOULUTUKSEEN}

OSALLISTUMISESTA ON

TULLUT YḦ̈ VAHVEMMIN

ITSEST $\ddot{A} \ddot{N}$ SELVÄ OSA

TYÖTё TAI TYÖTTÖMYYDEN

\section{VAIHTOEHTO.}


Aikuiskoulutuksessakin ulkoiset pakotteet ovat tulleet entistä merkittävämmiksi tekijöiksi koulutukseen osallistumisen syinä. Ilmeisimpiä nämä ulkoiset motiivit ovat työnantajan kustantamassa koulutuksessa ja työvoimapoliittisessa aikuiskoulutuksessa. Esimiehen tehdessä aloitteen koulutukseen osallistumisesta tarjouksesta ei ole helppo kieltäytyä, mikäli haluaa antaa itsestään kuvan sitoutuneena ja kehityskelpoisena työntekijänä. Varsinkin organisaatiohierarkian ylemmillä tasoilla koulutustapahtumista on tullut osa normaalia työntekoa.

Esimerkiksi Manninen (2004b, 197) panee kehittelemässään osallistumismallissa varsin paljon painoa yksilöllisille valinnoille ja eri koulutuksiin liitetyille mielikuville:

"Sen sijaan että osallistumista tarkasteltaisiin 'menneisyyden funktiona' tai jonkinlaisena systeemisenä vuorovaikutusprosessina, otetaankin tarkasteluun yksilö postmodernina toimijana ja päätöksentekijänä. Tällöin selitystä haetaan yksilön pääöksenteosta, erityisesti sellaisissa tilanteissa, joissa on paljon erilaisia vaihtoehtoja, mutta usein rajallinen määrä informaatiota päätöksenteon perusteeksi. Kun päätöksiä ei voi sitoa enää perinteen sanelemiin reunaehtoihin, korostuu esimerkiksi koulutusvalinnoissa näennäisen vapaa tahto, joka kuitenkin käytännössä saattaa korvautua varsin irrationaalisilla ja tunnepohjaisilla valinnoilla."

Edellä tekemämme tarkastelun perusteella suhtaudumme skeptisesti tällaiseen yhteiskunnallisesta asemastaan ja sosiokulttuurisista olosuhteista irrotetun postmodernin valitsijan selitysmalliin. Paradoksaalisesti, "yksilöllistyvien valintojen aikana" aikuisten osallistumisesta on tullut ehkä aiempaa vähemmän yksilön valinnan tulos. Koulutukseen osallistumisesta on tullut yhä vahvemmin itsestään selvä osa työtä (henkilöstökoulutus) tai työttömyyden vaihtoehto (työvoimakoulutus). Niin henkilöstökoulutukseen kuin työvoimapoliittiseen koulutukseen osallistumiseen aloite tulee usein yksilön itsensä ulkopuolelta joko esimieheltä tai työvoimaviranomaiselta.

Pyrittäessä selittämään aikuiskoulutukseen osallistumista on entistä tärkeämpää täsmentää, mitä aikuiskoulutuksella tarkoitetaan, koska koulutuksen kysynnän ja tarjonnan mekanismit poikkeavat aikuiskoulutuksen eri muodoissa niin paljon toisistaan. Aikuiskoulutuksen kasautuminen kuvastaa osaltaan juuri sitä, kuinka vahvasti aikuiskoulutus kytkeytyy yksilöiden sosioekonomisiin voimavaroihin ja luokkakohtaisiin kulttuureihin. Työelämän paineissa ahkerasti itseään kehittävän keskiluokan lisäksi on iso joukko ihmisiä, jotka tuntevat elävänsä hyvää elämää "ilman sitoutumista jatkuvan koulutuksen ja elinikäisen oppimisen eetokseen”, kuten Erja Moore (2004, 212) asian ilmaisee.

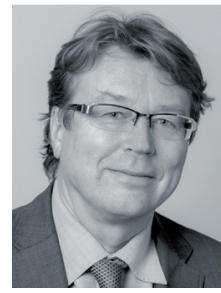

Heikki Silvennoinen

VTT

Kasvatustieteiden laitos

Turun yliopisto

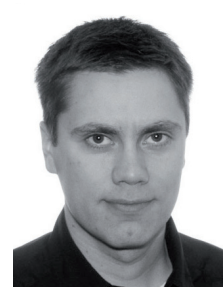

Matti Lindberg

VTT, erikoistutkija

Kasvatustieteiden laitos

Turun yliopisto 
Ahmed, W., \& Bruinsma, M. (2006). A structural model of self-concept, autonomous motivation and academic performance in cross-cultural perspective. Electronic Journal of Research in Educational Psychology 10(3), 551-576.

Antikainen, A. (2006a). In Search of the Nordic Model in Education. Scandinavian Journal of Educational Research 50(3), 229-243.

Antikainen, A .(2006b). Participation in Adult Education in a Nordic Context. Teoksessa A. Antikainen, P. Harinen \& C.A. Torres, C.A. (toim.) In from the Margins: Adult Education, Work and Civil Society. Rotterdam: Sense Publishers.

Antikainen, A. (2009). Aikuiskoulutukseen ja oppimiseen valikoitumisesta. Teoksessa P. Arajärvi \& A. Korhonen (toim.) Syrjäytymisen oikeudelliset pidäkkeet. Oikeustieteellisiä julkaisuja 24. Joensuu: Joensuun yliopisto, 193-207.

Antikainen, A. (2011). Kommentti osallistumistutkimuksesta. Aikuiskasvatus 31(2), 142-143.

Antikainen, A. \& Huusko, A. (2007). Tietotekniikan käyttö ja aikuiskoulutukseen osallistumisen sosioekonominen malli. Aikuiskasvatus(3), 164-172.

Antikainen, A. Rinne, R. \& Koski, L. (2014). Kasvatussosiologia. 5. uud. painos. Jyväskylä: PSKustannus.

Baert, H., De Rick, K. \& Van Valckenborgh, K. (2006). Towards the conceptualization of "Learning climate". Teoksessa R.V. De Castro, A.V. Sancho \& P. Guimares (toim.) Adult Education: New routes in a new landscape. Braga: University of Minho Press.

Ball, S. (1990). Politics and Policy-Making in Education: Explorations in Policy Sociology. London: Routledge.

Ball, S. (1994). Education Reform: A Critical and PostStructural Approach. Buckingham: Open University Press.

Ball, S. J. (2003). Class Strategies and The Education Market: the middle classes and social advantage. London: Routledge Falmer.

Beck, U. (1992). Risk Society: Towards a New Modernity. London: Sage

Beck, U. \& Beck-Gernsheim, E. (2002). Individualization: Institutionalized Individualism and its Social and Political Consequences. London: Sage.

Beck, U., Giddens, A. \& Lash, S. (1995). Nykyajan jäljillä: Refleksiivinen modernisaatio. (Reflexive modernization: Politics, tradition and aesthetics in the modern social order, 1994). Suom. Leevi Lehto. Tampere: Vastapaino.
Biesta, G. (2006). What's the point of Lifelong Learning if Lifelong Learning Has No Point? On the Democratic Deficit of Policies for Lifelong Learning. European Educational Research Journal 5(3 \& 4), 169-180.

Boeren, E., Holford, J., Nicaise, I. \& Baert, H. (2012). Why do adults learn? Developing a motivational typology across 12 European countries. Globalisation, Societies and Education 10(2), 247-269.

Boeren,E., Nicaise, I. \& Baert, H. (2010). Theoretical models of participation in adult education: the need for an integrated model. International Journal of Lifelong Education 29(1), 45-61.

Borg, C. \& Mayo, P. (2005). The EU Memorandum on lifelong learning. Old wine in new bottles? Globalisation, Societies and Education 3(2), 203-225.

Boschier, R. (1973). Educational participation and dropout: A theoretical model. Adult Education 23, 255-282.

Boudard, E. \& Rubenson,K. (2003). Revisiting major determinants of participation in adult education with a direct measure of literacy skills. International Journal of Educational Research 39(3), 265-281.

Bourdieu, P. (1984). Distinction. A social criticue of judgement of taste. Cambridge: Harward University Press.

Bourdieu, P.; Wacquant, L. (1992). An Invitation to Reflexive Sociology. Chicago and London: University of Chicago Press.

Centeno, V. (2011). Lifelong learning: a policy concept with a long past but a short history. International Journal of Lifelong Learning 30(2), 133-150.

Cookson, P. (1986). A Framework for Theory and Research on Adult Education Participation. Adult Education Quarterly 36(3), 130-141.

Courtney, S. (1992). Why Adults Learn: Towards a Theory of Participation in Adult Education. London: Routledge.

Cross, K. (1981). Adults as Learners. San Francisco: Jossey- Bass.

Darkenwald, O. \& Merriam, S. (1982). Adult Education: Foundations to practice. Massachusetts: Harper \& Row.

Deci, E. L., \& Ryan, R. M. (2000). The "what" and "why" of goal pursuits: Human needs and the selfdetermination of behavior. Psychological Inquiry 11, 319-338.

Dehmel, A. (2006). Making a European area of lifelong learning a reality? Some critical reflections on the European Union's lifelong learning policies. Comparative Education 42(1), 49-62.

Desjardins, R. \& Rubenson, K. (2013). Participation Patterns in Adult Education: the role of institutions 
and public policy frameworks in resolving coordination problems. European Journal of Education 48(2), 262-280-

Eurydice 2015. Adult Education and Training in Europe: Widening Access to Learning Opportunities. Eurydice Report. Luxembourg: Publications Office of the European Union.

Fejes, A. (2010). Discourses on employability: constituting the responsible citizen. Studies in Continuing Education 32(2), 89-102.

Fejes, A., \& Nicoll, K. (eds) (2008). Foucault and lifelong learning: Governing the subject. London: Routledge.

Foucault, M. (1991). Governmentality. In G. Burchell, C. Gordon \& P. Miller (toim.) The Foucault Effect. London: Harvester Wheatsheaf, 87-104.

Foucault, M. (2010). The Govenrment of Self and Others. Lectures at the Collége de France 1982-1983. New York: Palgrave Macmillan.

Giddens, A. (1990). The Consequences of Modernity. Cambridge: Polity.

Giddens, A. (1991). Modernity and Self-Identity. Self and Society in the Late Modern Age. Cambridge: Polity.

Illeris, K. (2004). What is Significant for Adults' Learning? Teoksessa M. Radovan \& N. Dordevic (toim.) Current Issues on Adult Learning and Motivation. Ljubljana: Slovenian Institute for Adult Education SIAE.

Järvensivu, A. \& Koski, P. (2012). Combating Learning. Journal of Workplace Learning 24(1), 5-18.

Kaisto, J. \& Pyykkönen, M. (toim.) (2011). Hallintavalta. Helsinki: Gaudeamus.

Kinnari, H. \& Silvennoinen, H. (2015). Elinikäinen oppiminen hallinnan teknologiana. Teoksessa E. Harni (toim.) Kontrollikoulu. Näkökulmia koulutukselliseen hallintaan ja toisinoppimiseen. Jyväskylä: Kampus Kustannus, 109-136.

Koski, L. (2011). Sivistystyön ihmiskäsitys: villi-ihmisestä aikuiseksi yksilöksi. Teoksessa A. Heikkinen \& P. Leino-Kaukiainen (toim.) Valistus ja koulunpenkki: kasvatus ja koulutus Suomessa 1860-luvulta 1960-luvulle. Helsinki: SKS, 159-183.

Lehtonen, H. \& Tuomisto, J. (1972). Aikuiskoulutukseen osallistuminen. Teoreettinen prosessimalli. Aikuiskasvatuksen laitos, tutkimuksia ja selvityksiä 1. Tampere: Tampereen Yliopisto.

Lehtonen, H. \& Tuomisto, J. (1974). Aikuiskoulutus Suomessa: käsitykset ja käyttö. Yhteiskuntatieteiden tutkimuslaitos. Tutkimuksia A:45. Tampere: Tampereen yliopisto.
Lyly-Yrjänäinen, M. (2014). Työolobarometri. TEM raportteja 9/2014. Helsinki: Työ- ja elinkeinoministeriö.

Manninen, J. (1989). Aikuiskoulutukseen osallistuminen. Osallistumista selvittävien mallien tarkastelua. Aikuiskoulutuksen 1. tutkijatapaaminen. Tampereen yliopiston aikuis- ja nuorisokasvatuksen laitoksen julkaisuja 25/1989, 24-32.

Manninen, J. (2004a). Adult Participation in Dream Society: Images of Adult Education. Teoksessa Current Issues in Adult Learning and Motivation. Ljubljana: Slovenian Institute for Adult Education, 69-82.

Manninen, J. (2004b). Mielikuvat ohjaavat aikuisten osallistumista koulutukseen. Aikuiskasvatus 24(3). 196-205.

Manninen, J. (2005). Development of Participation Models. From single predicting elements to complex system models.

Manninen, J., Mannisenmäki, E, Luukannel, S. \& Riihilä, S. (2003). Elinikäisen oppimisen tuska ja kurjuus? Aikuisten koulutusta ja oppimista koskevat mielikuvat. Raportteja ja selvityksiä 43. Helsinki: Palmenia-kustannus.

Moore, E. (2004). Aikuiskoulutukseen osallistumattomuus on myös rationaalista. Aikuiskasvatus 24(3), 206-213.

Nesbit, T. (2005). Social Class and Adult Education. Teoksessa T. Nesbit (toim.) Class Matters. New Directions for Adult and Continuing Education 106, $5-14$.

Nesbit, T. (2011). Class Analysis in Adult Education. Teoksessa K. Rubenson (toim.) Adult Learning and Education. Oxford: Elsevier, 238-243.

Nicoll, K. \& Fejes, A. (2008). Mobilizing Foucault in Studies of Lifelong Learning. In A. Fejes \& K. Nicoll (toim.) Foucault and Lifelong Learning. London: Routledge, 1-18.

Niemi, H. \& Ruuskanen, T. \& Seppänen, T. (2014). Osallistuminen aikuiskoulutukseen vuonna 2012. Suomen virallinen tilasto. Tilastokeskus, Helsinki.

OECD (2003). Beyond rhetoric: Adult learning policies and practices, the final report of the OECD thematic review on adult learning. Paris: OECD Publishing.

OECD (2013). OECD skills outlook 2013: First results from the survey of adult skills. Paris: OECD Publishing.

Olsen, M. (2008). Understanding the Mechanisms of Neoliberal Control: Lifelong Learning, Flexibility and Knowledge Capitalism. In A. Fejes \& K. Nicoll (toim.) Foucault and Lifelong Learning. London: Routledge, 34-47. 
Pellinen, P. (2001). Aikuiskasvatuksen ammatillistuminen. Katsaus aikuisoppilaitosten tehtäväkuvan historialliseen muotoutumiseen 1900-luvulla. Kasvatustieteiden tiedekunnan julkaisuja B 68. Turku: Turun yliopisto.

Rinne, R., Kivinen, O. \& Ahola, S. (1992). Aikuisten kouluttautuminen Suomessa. Osallistuminen, kasautuminen ja preferenssit. Koulutussosiologian tutkimusyksikön tutkimusraportteja 10. Turun yliopisto.

Rinne, R. \& Vanttaja, M. (1999). Suomalaista aikuiskoulutuspolitiikkaa. Muutoksia ja jännitteitä 1980- ja 1990-luvuilla. Koulutus- ja tiedepolitiikan julkaisusarja 67. Helsinki: Opetusministeriö.

Rose, N. (1999). Powers of Freedom. Reframing Political Thought. Cambridge: Cambridge University Press.

Rothes, A., Lemos, M \& Gonçalves, T. (2014). Motives and beliefs of learners enrolled in adult education. Procedia - Social and Behavioral Sciences 112. 939-948.

Rubenson, K. (1977). Participation in Recurrent Education. Paris: OECD.

Rubenson, K. (1979). Recruitment to Adult Education in the Nordic Countries - Research and Outreaching Activities. Reports on Education and Psychology 3. Stockholm Institute of Education, Department of Educational Research.

Rubenson, K. (1982). Adult Education Research: In Quest of a Map of the Territory. Adult Education Quarterly 32(2), 57-74.

Rubenson, K. (2001). The Adult Education and Training Survey. Measuring Motivation and Barriers in the AETS: A Critical Review. Human Resources Development Canada. R-01-9-2E. http://www. hrdc-drhc.gc.ca/sp-ps/arb-dgra/publications/ research/2001docs/R-01-9-2/R-01-9-2_E_abs. shtml.

Rubenson, K. (2005). Social Class and Adult Education Policy. Teoksessa T. Nesbit (ed) Class Matters. New Directions for Adult and Continuing Education 106, 15-25.

Rubenson, K. (2006). The Nordic model of lifelong learning. Compare 36, 327-341.

Rubenson, K. (2011). The Field of Adult Education: An Overview. Teoksessa K. Rubenson (toim.) Adult Learning and Education. Amsterdam: Elsevier, 3-13.

Rubenson, K. \& Desjardins, R. (2009). The Impact of Welfare State Regimes on Barriers to Participation in Adult Education. Adult Education Quarterly 53(3), 187-207.

Rubenson, K. \& Maret, E. (2015). Adult education research: exploring an increasingly fragmented map. European Journal for Research on the Education and Learning of Adults 6(2), 125-138
SA 1194/2003. Sosiaali- ja terveysministeriön asetus terveydenhuollon henkilöstön täydennyskoulutuksesta.

Savage, M. (2000). Class analysis and social transformation. Buckingham : Open University Press.

Silva, T., Cahalan, M. \& Lacireno-Paquet, N. (1998). Adult Education Participation Decisions and Barriers: Review of Conceptual Frameworks and Empirical Studies. Washington, DC: Department of Education.

Silvennoinen, H. (2002). Koulutus marginalisaation hallintana. Helsinki: Gaudeamus.

Silvennoinen, H. (2012). Elinikäisen oppimisen eurooppalainen standardimalli ja poikkeavuus. Teoksessa $\mathrm{H}$.

Silvennoinen, H. (2013). Aikuisten osallistuminen koulutukseen 2012. Aikuiskasvatus 33(3), 230-233.

Silvennoinen, H. (2014). Käänteentekijät: aikuiskoulutuksen vaikuttajia 1980-luvulta 2010-luvulle. Teoksessa K. Kantasalmi \& M. Nest (toim.) Valistajia, sivistäjiä, poliitikkoja ja asiantuntijoita: näkökulmia aikuiskasvatuksen kentän vaikuttajiin. Tampere: Tampere University Press, 341-382.

Silvennoinen, H. \& Lindberg, M. (2015). Tasaarvo työelämän koulutuksessa. Teoksessa Kasvatussosiologian vuosikirja 1 (tulossa).

Silvennoinen, H. \& Pihlaja, P. (toim.) (2012). Rajankäyntejä: tutkimuksia normaaliuden, erilaisuuden ja poikkeavuuden tulkinnoista ja määrittelyistä. Kasvatustieteellinen tiedekunta A214. Turku: Turun yliopisto, 85-111.

Skeggs, B. (2004). Class, Self, Culture. London: Routledge.

TEM (2008). Työvoimapoliittisen aikuiskoulutuksen vuositilastot vuonna 2007. Tilastotiedote 2008:3. Helsinki: Työ- ja elinkeinoministeriö.

TEM (2014). Työvoimakoulutuksen vuositilastot vuonna 2013. Tilastotiedote 2014:3. Helsinki: Työ- ja elinkeinoministeriö.

Tilastokeskus (2013). Aikuiskoulutustutkimus 2012 ennakkotiedot. Helsinki: Tilastokeskus.

Ward, S. (2012). Neoliberalism and the Global Restructuring of Knowledge and Education. London: Routledge. 


\section{Liite 1. Aikuiskoulusta antavia}

koulutusorganisaatiota AKU2012 -aineistossa

- Aikuis-ja iltalukiot

- Oppisopimuskoulutus

- Ammatillisten oppilaitosten aikuisille tarkoitetut tutkintoon johtavat ja johtamattomat kurssit

- Ammattikorkeakoulujen aikuisille tarkoitetut tutkintoon johtavat ja johtamattomat kurssit

- Yliopistojen/korkeakoulujen ammatillinen täydennyskoulutus

- Yliopistojen/korkeakoulujen erilliseen arvosanaan johtavat kurssit ja avoimen yliopiston kurssit

- Kesäyliopisto

- Kansanopistojen tai -korkeakoulujen ammatillisen kelpoisuuden antava koulutus sekä muu koulutus

- Musiikkioppilaitosten muu kuin ammatillisen kelpoisuuden antava koulutus
- Urheiluopistojen muu kuin ammatillisen kelpoisuuden antava koulutus

- Kansalais- ja työväenopistojen kurssit

- Kielikoulujen tai -opistojen kurssit

- Järjestöt, liitto tai yhdistys

- Opintokeskuksen opintokerho tai kurssi

- Tanssikoulu tai -opisto

- Työnantajan järjestämä koulutus

- Koulutusyritys tai koulutuskeskus

- Konferenssit, seminaarit yms.

- Jokin muu koulutus

- Työn yhteydessä saatu opastus

Liitetaulukko 1. Työhön ja ammattiin liittyvän aikuiskoulutuksen jakautuminen koulutustyyppeihin: osuus kursseista ja koulutuspäivistä (\%)

\begin{tabular}{|l|c|c|}
\hline KOULUTUSTYYPPI & $\begin{array}{l}\text { OSUUS } \\
\text { KURSSEISTA \% }\end{array}$ & $\begin{array}{c}\text { OSUUS KOULU- } \\
\text { TUSPÄIVISTÄ \% }\end{array}$ \\
\hline A. Henkilöstökoulutus: ulkoinen & 26 & 17 \\
\hline B. Henkilöstökoulutus: työpaikkakoulutus & 57 & 33 \\
\hline C. Henkilöstökoulutus: formaali & 2 & 8 \\
\hline D. Muu työpaikalla tapahtuva koulutus & 3 & 2 \\
\hline E. Formaali koulutus & 3 & 26 \\
\hline F. Muu non-formaali koulutus & 9 & 14 \\
\hline Yhteensä & 100 & 100 \\
\hline
\end{tabular}

Liitetaulukko 2. Harrasteperustaisen koulutuksen jakautuminen koulutustyyppeihin: osuus kursseista ja koulutuspäivistä (\%)

\begin{tabular}{|l|c|c|}
\hline KOULUTUSTYYPPI & $\begin{array}{l}\text { OSUUS } \\
\text { KURSSEISTA \% }\end{array}$ & $\begin{array}{l}\text { OSUUS KOULU- } \\
\text { TUSPÄIVISTÄ \% }\end{array}$ \\
\hline G1. VST: non-formaali & 60 & 53 \\
\hline G2. VST: formaali & 1 & 6 \\
\hline H. Muu non-formaali & 39 & 41 \\
\hline Yhteensä & 100 & 100 \\
\hline
\end{tabular}

